\title{
Method of evaluating the economic efficiency of waste utilization from trade enterprises
}

\author{
Oksana Pirogova ${ }^{1}$, Timur Kurbanov², Vladimir Plotnikov ${ }^{3,4, *}$ \\ ${ }^{1}$ Peter the Great St. Petersburg Polytechnic University, Institute of Industrial Management, \\ Economics and Trade, Graduate School of Service and Trade, 29, Polytechnicheskaya str., Saint \\ Petersburg, Russia, 195251 \\ ${ }^{2}$ General Khrulev Military Academy of Logistics and Procurement, 8, Makarov emb., Saint \\ Petersburg, Russia, 190000 \\ ${ }^{3}$ Saint-Petersburg State University of Economics, 21, Sadovaya str., Saint Petersburg, Russia, 191023 \\ ${ }^{4}$ South-West State University, 94, 50 let Oktyabrya str., Kursk, Russia, 305040
}

\begin{abstract}
The article analyses the implementation of the principles of environmental self-restoration and dynamic adaptability of trade enterprises. Solving the problems of introducing environmental aspects of sustainable development into the activities of trade enterprises and developing waste disposal methodologies are important tasks for the country's economy. It is offered to develop a methodology (system) of waste processing, which are formed in the process of consumption of commodity-material values in trade. The methodology includes the following factors: cost-effectiveness, social significance of disposal, safety of waste processing, resource saving, environmental reputation. The method includes several stages: analysis of the regulatory framework, the settlement and analytical stage, and the final stage - the assessment of economic efficiency. The main difference between the method and the one developed earlier is in an integrated approach to justifying the creation of a modern waste treatment system in commercial enterprises. The offered method develops the theory of economic and investment analysis, as well as the theory of making management decisions in managing the development of commercial enterprises.
\end{abstract}

\section{Introduction}

In recent years, the concept of business as an activity whose sole purpose is to make a profit in the world community has changed significantly. Today, business is viewed as a human activity, which is inextricably linked with both social and environmental aspects [1-3, etc.]. Managers and business owners in various sectors of the economy face new challenges. One of the important tasks for business is to solve the question of how to combine the increase in the efficiency of economic activity with a decrease in the negative impact on the environment and the increase in energy efficiency.

\footnotetext{
*Corresponding author: plotnikov_2000@mail.ru
} 
For enterprises of the trade industry, these tasks are also relevant [4-6, etc.]. The trade industry today is one of the fastest growing sectors of the global economy, which not only ensures the distribution of finished consumer goods, but also creates millions of jobs. On the other hand, active commercial activity leads to a negative environmental impact.

As the main environmentally harmful factors in the activities of trade enterprises, such factors as high energy consumption, high water consumption, high levels of waste, carbon dioxide emissions, greenhouse gases and ozone-depleting gases, etc. can be noted. These factors manifest themselves in the process of transporting goods, inefficient storage, etc., so it is necessary to raise the question of the transition of trade enterprises to a model of sustainable development, in which the interests of future generations are put on a par with the interests of today's generations.

The relevance of this article is due to the growing role of international environmental organizations, such as Greenpeace, UNEP, the World Wide Fund for Nature and others, together with the growing trend of the so-called "green consumption" (consisting in the acquisition, use and processing of environmentally friendly products and services) lead to the fact that more and more companies are forced to take measures to reduce their negative impact on the environment [7-10, etc.].

\section{Materials and methods}

Analysis of the problem of sustainable environmental development of trade enterprises is based on the use of traditional methods of economic research. In conducting the study, we used economic-statistical and investment methods, comparative, systemic and structural analysis, industry analysis, content analysis, and also a method of expert assessment.

Currently, advanced global companies in various sectors of the economy are increasingly paying attention to their image, which is largely influenced by the company's contribution to solving global social and environmental problems [11, 12, 13]. Among consumers, especially in developed countries, there is also a growing interest in goods and services that do less harm to the environment than their counterparts do. To increase their social responsibility, large companies are actively involved in the work of providing information about their own contribution to sustainable development. Currently, sustainability reporting is evolving in several ways. One of such areas is reporting on corporate social responsibility.

Currently, the ISO 26000: 2010 "Guide to Social Responsibility" has been developed and put into effect. This standard reveals the essence of corporate social responsibility and its role in the overall system for ensuring sustainable development. The main point of this standard is the statement that the corporate responsibility of a business can has a significant positive impact on the state of development of society and make a significant contribution to the implementation of the basic principles of sustainable development. In accordance with the standard, corporate social responsibility is the responsibility of an organization for the impact of its decisions and activities on society and the environment through transparent and ethical behavior. The standard defines the following criteria for the ethical behavior of an organization:

1. Promoting sustainable development.

2. Interaction with all stakeholders.

3. Promoting applicable law and consistency with international standards of conduct.

4. The principles of ethical behavior are integrated into the main strategy of the organization and are applied in its relations with other organizations.

The standard also reveals the main aspects of social responsibility:

1. Organizational management.

2. Human rights. 
3. Labor practices.

4. Environment.

5. Fair business practices.

6. Problems associated with consumers.

7. Participation in the life of communities and their development.

As can be seen from the content of corporate social responsibility, one of its elements is the environment, i.e. in accordance with the standard, when compiling a report on corporate social responsibility, a company should reflect its contribution to reducing the burden on the environment. However, it is obvious that this aspect is an environmental aspect. The concept of sustainable development is based on the organic interaction of three elements the economy, ecology and social sphere. These aspects are equal in terms of significance, it is on the interconnection of these three aspects that it is possible to achieve a synergistic effect and solve the most complex development tasks facing humanity.

The basic tenet of the ecological approach in the concept of sustainable development is the thesis that meeting the needs of the present should not reduce the possibilities for future generations to exist. This thesis implies a gradual abandonment of non-renewable sources and the transition to the use of renewable sources in their activities, the full reduction of the environmental burden on the environment. From an environmental point of view, sustainable development should ensure the integrity of natural systems and habitats in the broad sense of the word, including the human-created environment, such as human settlements, and the focus should be on maintaining and developing the ability to heal and dynamically adapt to change.

In our opinion, this situation is because at present the ecology and environmental aspects are considered in the narrow sense of environmental protection activities. If you turn to the legislation, including domestic, then it basically has an environmental focus, and defines the standards of environmental safety, which involve maintaining the influence of harmful factors in the acceptable ranges. This is also due to the lack of a unified view of the definition of ecology. Currently, ecology is an interdisciplinary science of the interaction of man, organizations and human society with the environment. Those. modern understanding of ecology should be much broader. This is not only environmental protection, energy conservation and reduction of environmental impact, but also the empowerment of the "man-society-nature" system for self-healing and dynamic adaptation.

Another major problem that hampers the implementation of environmental initiatives and innovations in the activities of trade enterprises is the lack of clear methods for assessing the positive economic effect and reducing the level of environmental risks. The fact is that most of the environmental initiatives cause a delayed positive effect, i.e. the positive effect is manifested only after a certain time. At the same time, the company now incurs the cost of the environmental initiative.

\section{Results}

Russian trade enterprises are trying to introduce modern environmental innovations and ways of doing business that can reduce the impact on the environment. At present, the following main directions for the implementation of environmental innovations in the activities of commercial enterprises can be distinguished [14-16]:

1. Work with packaging. The refusal of free disposable plastic packaging and the introduction of reusable packaging or packaging made from recycled materials can significantly reduce the use of plastic bags and as a result reduce environmental pollution.

2. Optimization of logistics. The use of modern logistics terminals and optimization of routes and time of delivery of goods to retail outlets can reduce vehicle mileage, gasoline costs, as well as reduce carbon dioxide emissions into the atmosphere. 
3. The use of energy and resource saving technologies in trade and technological processes. The use of environmentally friendly and energy-saving lamps in lighting can significantly reduce environmental pollution with mercury, as well as reduce the cost of both electricity and the lighting devices themselves, since the operating time of LED lamps is 10-100 times longer than traditional mercury daylight lamps. The use of modern refrigeration equipment operating on non-ozone-depleting refrigerants is also noted.

4. Reducing the consumption of paper on advertising. The job of reducing paper consumption for advertising is to reduce paper consumption for advertising products.

5. Use of renewable energy sources. Foreign retailers actively use renewable energy sources to reduce their environmental impact. So, Tesco is trying to use rainwater and solar energy utilization systems.

One of the promising areas of environmental innovations of the Russian Federation is the waste recycling system of the trading process. In accordance with the Decree of the President of the Russian Federation of January 5, 2016 No. 7 "On the Year of Ecology in the Russian Federation" and the Order of the Government of the Russian Federation of June 2, 2016 No. 1082-p, it is offered to develop a methodology (system) for processing waste generated in the process of consumption of inventory in trade. When developing the methodology, it is necessary to consider a number of factors, which include:

1. Profitability - despite the relatively high cost of separation and recycling, economic efficiency is achieved due to the recycled materials used to produce various products (modern technologies and the ability to manage the system from the initial moment of waste generation to the final moment of processing ensure high profitability of their reuse).

2. The social significance of recycling is the creation of additional high-tech jobs and an increase in the employment of able-bodied citizens in the region (increased efficiency in the use of labor resources). Reasonable waste management has a positive effect on the sanitaryepidemiological situation - the incidence of the population is decreasing.

3. Waste recycling safety - use only safe methods and methods of disposal of waste generated by consumers. The risk of negative impact on human life and health, as well as on the environment, is reduced to the minimum value at all stages of waste conversion into recycling materials, starting with garbage collection.

4. Resource conservation - rational use of resources with full satisfaction of the increase in demand due to the use in the production of recycled materials (regeneration and recovery of materials or the release of useful energy during thermal utilization). The absence of landfills or their minimum number allows using the vacated lands for other purposes.

5. Environmentally friendly - the preservation of the environment. Thanks to recycling, the negative impact on nature is reduced by reducing the amount of buried waste at landfills, using safe waste disposal methods, as well as using recycled materials (reducing the amount of resources produced).

6. Reputation is a qualitative and quantitative intangible indicator of the activities of a commercial enterprise, which is a well-established public opinion. Waste can be easily identified, and finding them in landfills, especially unauthorized, including those formed through the fault of companies responsible for the removal and disposal of waste, can adversely affect the reputation of the trade organization. It is also worth noting that the separate collection and recycling of waste will significantly increase the prestige of the enterprise in society.

\section{Discussion}

We proposed some new models of recycling in trade. The method of environmental and economic rationale for the creation of a modern waste management system at commercial enterprises includes several stages (see Figure 1). 


\section{1} The first stage (preparatory)

Analysis of the existing regulatory framework for waste processing

Analysis of types and classification of waste of commercial enterprises

Study and selection of preferred technologies for processing waste of commercial enterprises in recyclable materials

Formation of requirements to the waste processing system of commercial enterprises

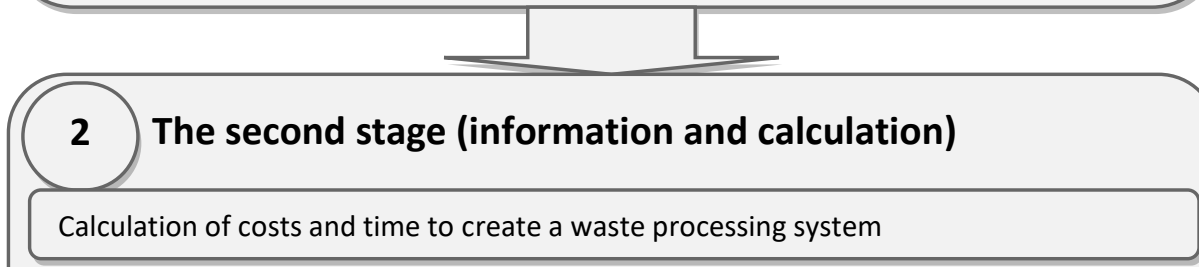

Calculation of operating costs for the operation of the system within one period

Calculation of direct and indirect revenue streams from waste recycling at a commercial enterprise

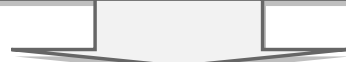

\section{The third stage (investment and analytical)}

Calculation of the payback period of the waste processing system

Calculation of indicators of economic efficiency of the investment project to create a system of waste processing at the trading enterprise

The decision to create a waste recycling system at a commercial enterprise

Source: compiled by Oksana Pirogova.

Fig. 1. The scheme of introduction of waste recycling system in trade enterprises

Stage 1 - analysis of the regulatory framework - to consider existing modern technologies for waste processing, as well as to clarify the classification of waste (to organize separate waste collection, you must choose an existing waste classification or develop your own). 
Stage 2 - settlement and analytical - it is necessary to determine the cost of creating a waste treatment system and calculate operating costs. At this stage, it is necessary to assess the upcoming costs of construction, equipment, the cost of automating the process of recycling, the cost of recycling, the cost of storing waste, as well as the costs associated with transporting waste.

Stage 3 - assessment of economic efficiency. At this stage, it is necessary to calculate the net present value (NPV); profit index (PI); internal rate of return (IRR); discounted payback period (DPP) [17-20, etc.].

With NPV $>0$, investment in a project for a modern waste treatment system is economically efficient, with NPV $=0$, it indicates that the project will require government support. The need for waste disposal is confirmed by the fact that, in addition to economic interest, this project has other equally important indicators of importance - it is the environmental performance of a commercial enterprise, the social significance of the project, the organization's reputation, etc. At NPV $<0$, when the project does not bring any profit, but it will be unprofitable, most likely to be rejected.

\section{Conclusion}

Summing up, it is worth noting that at present only an insignificant part of the waste is recycled, the task of the effectiveness of the design, development and implementation of the recycling system remains little studied. Issues of evaluating the effectiveness of waste disposal of commercial enterprises remain little studied, therefore, the method given in the article deserves attention both from theoretical and practical points of view.

The main difference between the method and the one developed earlier is an integrated approach to justifying the creation of a modern waste treatment system in commercial enterprises. The proposed method develops the theory of economic and investment analysis, as well as the theory of making management decisions in the management of the development of commercial enterprises.

The paper is an output of the science project of the government task of Ministry of education and science of the Russian Federation \# 26.3546.2017/PCH "Development fundamentals of analysis and prediction of structural and dynamic parameters of the regional economy are based on the integration of the Russian and world experience of management of territorial development and modern scientific doctrines".

\section{References}

1. S. Kara, S. Ibbotson, B. Kayis, Journal of Manufacturing Technology Management, 25(6), pp. 848-872 (2014)

2. L. Salamon, Leverage for Good: An Introduction to The New Frontiers of Philanthropy and Social Investment, Oxford University Press (2014)

3. Y. V. Vertakova, A. V. Polyanin, T. A. Golovina, European Research Studies Journal, 21, pp. 1001-1012 (2018).

4. C. A. Brandi, Sustainable Development, 25(1), pp. 25-34 (2017)

5. W. Nakawiroj, International Journal of Economic Policy in Emerging Economies, 9(3), pp. 272-289 (2016)

6. J. Waleson, Legal Issues of Economic Integration, 42(2), pp. 143-174 (2015)

7. C. Bai, P. Shah, Q. Zhu, J. Sarkis, Industrial Management and Data Systems, 118(2), pp. 349-389 (2018)

8. M. Jo, J. Shin, International Journal of Consumer Studies, 41(3), pp. 283-290 (2017) 
9. M. A. Ülkü, J. Hsuan, Journal of Cleaner Production, 142, pp. 4230-4242 (2017)

10. Y. Vertakova, V. Plotnikov, Economic Annals-XXI, 166(7-8), pp. 4-10 (2017) doi: 10.21003/eaV166-01.

11. E. M. Schau, M. Traverso, M. Finkbeiner, Journal of Remanufacturing, 2(1), p. 5 (2012)

12. Q. Wang, X. Yuan, X. Cheng, R. Mu, J. Zuo, Ecological Indicators, 46, pp. 514-523 (2014)

13. A. D. Charnetsky, Solid household waste, 10, pp. 68-69 (2007)

14. E. J. Malecki, B. Moriset, The digital economy: Business organization, production processes and regional developments, (London, Routledge, 2007)

15. D. Helbing, Thinking ahead-essays on big data, digital revolution, and participatory market society, Springer (2015)

16. S. Graham, D. Wood, Critical Social Policy, 23(2), pp. 227-248 (2003)

17. T. A. Burtseva, V. I. Aleshnikova, M. V. Dubovik, K. V. Naidenkova, N. B. Kovalchuk, N. V. Repetskaya, O. G. Kuzmina, A. A. Surkov, O. I. Bershadskaya, A. V. Smirennikova, International Journal of Environmental and Science Education, 11(15), pp. 8182-8192 (2016)

18. V. Plotnikov, O. Pirogova, Proceedings of the 31st International Business Information Management Association Conference (IBIMA), pp. 1716-1721 (Milan, Italy, 2018)

19. D. Tikhomirov, V. Plotnikov, MATEC Web of Conferences, 193, 05069 (2018) doi.org/10.1051/matecconf/201819305069.

20. Y. Vertakova, A. Kurbanov, Proceedings of the 28th International Business Information Management Association Conference - Vision 2020: Innovation Management, Development Sustainability, and Competitive Economic Growth, 21582167 (2016). 